\title{
Law Enforcement Of Narcotics Laws
}

\section{Asep Iswahyudi Rachman*) and Sri Kusriyah ${ }^{* *}$ )}

*) Student of Masters (S2) of Law Faculty of Law Unissula and Central Java Police Officer Semarang, Central Java, Email: svteams08@gmail.com.

${ }^{* *}$ ) Faculty of Law Universitas Islam Sultan Agung

\begin{abstract}
This study aims to explore the law enforcement of the Republic of Indonesia Act No. 35 of 2009 on Narcotics by the Directorate of Drug Research at the Central Java Regional Police. An empirical juridical approach is used to study the phenomena that are the focus of research. Data collection techniques using data reduction, data presentation, triangulation and drawing conclusions. The results showed that the narcotics crime in the jurisdiction of the Central Java Regional Police was already at an unsettling stage and not only involved the adult group, but also touched teenagers and children. Law enforcement of Act No. 35 of 2009 concerning Narcotics" by the Central Java Regional Police's Narcotics Research Directorate is carried out by penal and non-penal. In the effort to enforce the law enforcement by means of the implementation of the Narcotics Law, there are still problems related to "defining the Chapter General Provisions of Act No. 35 of 2009 concerning" Narcotics. In defining "in the Chapter General Provisions of Act No. 35 of 2009 concerning Narcotics in its implementation it has an impact on the handling of narcotics addicts, narcotics abuse and victims of narcotics abuse with the dealers or dealers" of narcotics. The inhibiting factors in enforcing Act No. 35 of 2009 concerning Narcotics by" the Directorate of Drug Research at the Central Java Regional Police are the imbalance in the number of personnel / resources of the Central Java Regional Police's Narcotics Diresnarkoba with inadequate areas, facilities and infrastructure, especially technology-related facilities. (IT), and most importantly the low level of public awareness of the dangers of narcotics.

Keywords: Law Enforcement; Narcotics, penal and non penal
\end{abstract}

\section{Introduction}

Indonesia has become one of the countries that has become the most commercially prospective market-state for international syndicates from a network of illicit narcotics trafficking syndicates with an international dimension for commercial purposes. ${ }^{1}$ Narcotics have a big influence on the lives of narcotics abusers themselves. If drug abusers are addicted or dependent on illegal goods, they will do everything they can to obtain drugs and do not rule out the possibility of committing or committing acts that violate the laws in force in Indonesia, such as stealing, cheating, robbing and even committing. things that should not be done by the general public. This is in line with the statement of an expert who has long worked in the field of psychoactive drugs that at the compulsive stage of addiction, addicts always try not to feel that they experience withdrawal symptoms. The condition of withdrawal of drugs is always avoided, so that individuals will become dealers (drug suppliers). Apart from obtaining financial benefits, you will also have

${ }^{1}$ Raharjo, Trisno, Tinjauan Teoritik terhadap Kejahatan Narkotika sebagai Transnasional Organized Crime. University of Muhammadiyah Yogyakarta, 2015. 
the opportunity to use the drugs themselves. ${ }^{2}$ This negative impact is the source of destruction for the nation's future generations Joko Widodo's government is very concerned about and imposes conditions on Indonesia emergency Drugs. ${ }^{3}$

Narcotics and psychotropic crimes as referred to in the Law on Narcotics provide quite severe criminal sanctions, however in reality the perpetrators of crimes are increasing, and for convicted persons in reality are not deterred and there is a tendency to repeat them. This can be caused by the existence of a criminal imposition factor that does not have a deterrent effect on the perpetrators. ${ }^{4}$

The National Police, through their investigators, is expected to be able to carry out investigative duties in order to enforce the law on all forms of narcotics abuse. Article 1 point (1) Act No. 8 of 1981 concerning the Criminal Procedure Code, investigators are officers of the State Police of the Republic of Indonesia or officials of Civil Servants who are given special authority by law to carry out investigations. The task of the police as investigators plays a major role in the investigation and investigation of general criminal law, namely violations of the articles contained in the Act No. 35 of 2009 concerning Narcotics.

\section{Research Methods}

The approach method in this research is an empirical juridical approach. The research specification used is descriptive analytical. Sources of data used in research can be divided into primary legal materials, secondary legal materials, tertiary legal materials.

Data collection methods using interviews and literature. Data analysis was carried out inductively, which is looking for the truth by departing from things that are specific to things that are general in nature in order to obtain conclusions.

\section{Results And Discussion}

\subsection{Description of the narcotics crime in the jurisdiction of the Central Java Regional Police}

The characteristics of drug crime, especially Narcotics, are very different from other crimes considering that this crime is a neatly organized crime with the Operandi Mode which tends to always change and the perpetrators have used Couriers or with Modern Technology Tools, so that the whereabouts and activities of the perpetrators of drug abuse are increasingly difficult to trace. The revealed

\footnotetext{
${ }^{2}$ Gunarsa, Dari Anak sampai Usia Lanjut: Bunga Rampai Psikologi Perkembangan. Gunung Mulia, Jakarta, 2010.

3 Akuntono, Presiden Jokowi: Indonesia Gawat Darurat Narkoba. http://nasional.kompas.com/read/2015/02/04/10331931/Presiden.Jokowi.Indonesia.Gawat.Daru rat.Narkoba, 2015.

${ }^{4}$ Indah Lestari dan Sri Endah Wahyuningsih, Penegakan Hukum Pidana terhadap Pengguna Narkoba di Polda Jateng, Jurnal Hukum Khaira Ummah, Vol. 12. No. 3, Semarang, 2017, p. 601-602.
} 
results of drug crimes in the Central Java Regional Police in 2018, the number of 2366 cases, 2762 suspects. The results of the disclosure of drug crimes in the Central Java Regional Police in 2019, as many as 1845 cases, 2274 suspects.

Based on comparisons Narcotics crime in the Central Java Regional Police. The 2018 and 2019 as a whole has indeed experienced a decline. However, in drug cases it has actually increased. In 2018 there were 1305 cases of drug crime with 1649 suspects. This number increased in 2019, namely as much 1355 drug crime cases with as many suspects 1735 orang. Drug abuse in the Central Java Regional Police is very worrying. Drugs themselves are goods that are no longer considered haram items that are difficult to obtain, but goods that are very easy to obtain because of immediate needs as an addictive effect and enjoyment of the user's body. Drug addicts will justify any means to get this illicit item because drugs are indeed a substance that has a strong addictive effect for its users and an extraordinary addictive effect. If the dependence experienced by drug users is not realized, the effect experienced is withdrawal, which is a condition in which the person experiences anxiety or psychological or psychological disorders due to drug addiction.

The circulation of narcotics is at an alarming stage because it has touched students. The number of teenagers who become perpetrators of narcotics crimes is of course related to implementation Constitution Republic of Indonesia Number 35 of 2009 concerning Narcotics by the Directorate of Drug Research Central Java Police. This of course places teenagers as victims of narcotics crime, so that it has an impact on how the narcotics law is implemented in its proof. Child narcotics users are a group that is vulnerable to human rights violations, so that children need special protection and treatment, especially in fulfilling the right to health and access to justice.

Article 33 of the Convention on the Rights of the Child states that every country is obliged to take appropriate steps to protect children from the use of narcotics and the illicit trafficking of narcotics. Steps that can be taken by the state include legislative, administrative, social and educational steps. However, there are still many countries, one of which is Indonesia, which often uses the war approach on Narcotics by criminalizing the use of Narcotics, including the use of narcotics by children. This punitive policy has forced many children who use narcotics in Indonesia to undergo legal processes, including processes for restricting freedom such as detention. This process has a negative impact on children's growth and development, both physically and psychologically. In fact, based on the Convention on the Rights of the Child, the growth and development of children's lives is one of the basic principles that determine the fulfillment of other children's rights.

\subsection{Law Enforcement Republic of Indonesia Number 35 of 2009 concerning Narcotics by Directorate of Drug Research Central Java Police}

Law enforcement of the Act No. 35 of 2009 concerning Narcotics by the Central Java Regional Police's Drug Research Directorate is a concrete step taken to 
eradicate the circulation of narcotics in the jurisdiction of the Central Java Regional Police. The author's analysis with the theory of crime prevention as well as the existing theory in the theoretical framework, it is known that law enforcement of the Act No. 35 of 2009 concerning Narcotics by the Directorate of Drug Research at the Central Java Regional Police is carried out by means of penal and non-penal.

a. Counter measures Crime with Criminal law (Effort Penal)

According to Barda Nawawi Arief5that countermeasures through this penal route can also be referred to as efforts made through criminal law. This effort is a countermeasure that focuses more on repressive nature, namely actions taken after a crime has occurred by enforcing the law and imposing penalties for crimes that have been committed. Based on a document study at the Central Java Police's Ditresnarkoba, it is known that penal measures are always put forward to eradicate narcotics crime. This is manifested in several active raids and routine urine tests carried out by the Central Java Police's Ditresnarkoba.

1) Ditresnarkoba Central Java Regional Police carried out raids on discotheques / entertainment venues.

2) Ditresnarkoba Central Java Regional Police carried out prison raids.

3) Ditresnarkoba Central Java Regional Police carried out a urine test.

In the field of crime prevention with criminal law (Penal Effort), the Central Java Regional Police's Ditresnarkoba continues to strive to uncover cases of illicit trafficking of Narcotics and arrest the Narcotics syndicate network both nationally and internationally.

b. Crime Management Without Criminal Law (Non Penal Effort)

According to Barda Nawawi Arief, 6 that countermeasures through nonpenal channels can also be called efforts made through channels other than criminal law. "This effort is a prevention effort that focuses more on preventive nature, namely actions in the form of prevention before the occurrence of a crime. Through this non-penal effort the main objective is to deal with the factors conducive to the occurrence of crime, namely covering social problems or conditions that can directly or indirectly cause or promote crime.

Apart from carrying out repressive tasks, the Directorate of Drug Research also carries out preventive tasks. Ditresnarkoba Central Java Regional Police and its staff have carried out P4GN activities or counseling on the dangers of drug abuse targeting the community, students, students, toga, Thomas, NGOs, office employees of Jamaah Masjid, Church congregations, etc. 1441 times. Apart from the aforementioned outreach activities, P4GN activities are also carried out by using traditional art facilities which are held once a month, distributing brochures and magazines on the streets / crowded places. 


\subsection{Factors that Influence the Enforcement of Act No. 35 of 2009 concerning Narcotics by the Directorate of Drug Research at the Central Java Regional Police}

Law enforcement is an activity to harmonize the relationship of values that are outlined in solid and embodied principles, and attitude of action as a series of final value definitions, to create, maintain and maintain a peaceful life. Law enforcement does not merely mean the implementation of legislation or in the form of judges' decisions. Law enforcement must be carried out without discrimination. ${ }^{7}$ The main problem that afflicts law enforcement is the factors that influence it directly or indirectly. These factors have a neutral meaning so that they can cause positive impacts as well as negative impacts. In terms of the law enforcement factor, it makes a rule of law really function.

The author's analysis with the theory of law enforcement as the existing theory is in the theoretical framework, it is known that the enforcement of Act No. 35 of 2009 concerning Narcotics by the Directorate of Drug Research at the Central Java Regional Police is influenced by five factors, namely: 8

a. Factor the law itself is limited from the enactment of the law regarding the principles and objectives of impact positive

The existence of the Narcotics Law, namely the Act No. No. 35 of 2009 concerning Narcotics is a political and legal effort by the Indonesian government to tackle narcotics crime. The formation of the Narcotics Law is expected to be able to tackle illicit trafficking and abuse of narcotics by using criminal or penal law facilities.

Article 136 of Law no. 35 of 2009 provides sanctions in the form of narcotics and narcotic precursors as well as proceeds obtained from narcotics crime, both movable or immovable assets or tangible or intangible as well as goods or equipment used for narcotics crimes confiscated for the state. Article 146 also imposes sanctions on foreign citizens who have committed a criminal act of narcotics or have undergone a narcotics crime, namely the expulsion of the territory of the Republic of Indonesia and prohibited from re-entering the territory of the Republic of Indonesia. Whereas in Article 148, if the verdict of the fine stipulated in this law is not paid by the narcotics criminal, the perpetrator will be sentenced to a maximum of two years in prison as a substitute for a fine that cannot be paid.

b. Law enforcement factors.

So far, the eradication and handling of drug crimes still relies on law enforcement officials, community involvement is only in the form of counseling/ information about drugs. Even if there are community organizations dealing with this problem, they are only sporadic and have not shown real practices.

\footnotetext{
${ }^{7}$ Alvi, Syahri, 2020. Law Enforcement against Policies Who Breached the Code of Conduct, Jurnal Daulat Hukum, Vol. 3. Issue. 3, p. 313-320.

8Soekanto, Soerjono: 2013. Faktor-Faktor yang Mempengaruhi Penegakan Hukum, Rajawali, Jakarta, p. 4-34
} 
Professionally, in fact, law enforcement officers have not been able to completely solve drug eradication, this is due to a lack of professional / reliable human resources, on the other hand, there are no adequate facilities and infrastructure for complete disclosure of cases. Sometimes birocracy is a factor that causes / constrains the eradication of drug crime itself.

c. Factor facilities that support law enforcement so that it runs smoothly

The certainty of handling a case always depends on the input of resources given to prevention and eradication programs of criminal act. It is impossible for law enforcement to run smoothly without certain means or facilities that support the implementation. Based on a document study at the Central Java Police's Ditresnarkoba, it is known that there is support for facilities and infrastructure that support the prevention and eradication of narcotics crime. The existence of means of prevention or prosecution of narcotics crime will further support the eradication of the narcotics crime itself.

d. Factor Public.

The prevention of psychotropic crime based on Act No. 5 of 1997 and Act No. 22 of 1997, the Convention on Psychotropics, Substance 1971, and the Convention on the Eradication of the Illicit Circulation of Psychotropics and narcotics in 1988 requires public participation. The author's view in this matter is, in order to support law enforcement officials in dealing with psychotropic crime perpetrators, community participation is needed, because the facts prove that for psychotropic crime perpetrators, public participation is needed, because the facts prove that the perpetrators of psychotropic and narcotics crimes use the modus operandi of crime by involving countries outside the territorial boundaries. How complex the psychotropic problem is, it is impossible for law enforcers to solve it alone. Therefore, it is necessary to make use of community participation in order to prevent the illicit trafficking of psychotropic substances and narcotics.

e. Factor culture.

It is not possible to eradicate and overcome the perpetrators of drug crime, it is feared that there will still be many drug perpetrators / users who will come, given that there are still dealers for drug trafficking in society. This situation is inseparable from the culture in society that does not show concern or an active role in reporting any indication of the circulation of narcotics in their environment.

\section{Closing}

Description of the narcotics crime in the jurisdiction of the Central Java Regional Police is already at a troubling stage and does not only involve adults, but also touches youth and children. Law enforcement of the Narcotics Law by the Central Java Police's Narcotics Research Directorate is carried out by penal and non-penal. In the effort to enforce the penal law through the implementation of the Narcotics Law, there are still problems related to the definition in the Chapter 
General Provisions. Inhibiting factors in the enforcement of Act No. 35 of 2009 concerning Narcotics by the Central Java Regional Police's Narcotics Research Directorate is the imbalance between the number of personnel / resources of the Central Java Regional Police's Diresnarkoba with the region, inadequate ICT facilities, and low public awareness of the dangers of narcotics.

In order to prevent narcotics crime, Central Java Regional Police Diresnarkoba It is suggested that e-policing can support the strategy of policing in the prevention of narcotics crime in the jurisdiction of the Central Java Police. Central Java Regional Police Diresnarkoba in the application of e-policing, all existing data should be used, such as basic intelligence, personal data (e-KTP), or data on criminal incidents that are integrated into the database for build a Scientific Crime Investigation, so that the disclosure of narcotics crime will be faster. In addition, the Central Java Regional Police Diresnarkoba is also advised to build an e-Polmas. Through e-Polmas, every message of Kamtibmas related to the dangers of narcotics will be conveyed quickly so that it is narcotics prevented crime in the jurisdiction of the Central Java Regional Police, it will be even more effective.

\section{References}

[1] Gunarsa, Dari Anak sampai Usia Lanjut: Bunga Rampai Psikologi Perkembangan. Gunung Mulia, Jakarta, 2010.

[2] Raharjo, Trisno, Tinjauan Teoritik terhadap Kejahatan Narkotika sebagai Transnasional Organized Crime. University of Muhammadiyah Yogyakarta, 2015.

[3] Soekanto, Soerjono: 2013. Faktor-Faktor yang Mempengaruhi Penegakan Hukum, Rajawali, Jakarta

\section{Regulations}

[1] Act No. 5 of 2009 concerning the Ratification of the United Nations Convention Against Transnational Organized Crime

[2] Constitution Republic of Indonesia Number 35 of 2009 concerning Narcotics.

[3] Convention on Psychotropica Substances 1971

[4] Convention Against Traffic in Narcotic Drugs and Psykotropic Substances 1988.

\section{Journals}

[1] Indah Lestari dan Sri Endah Wahyuningsih, Penegakan Hukum Pidana terhadap Pengguna Narkoba di Polda Jateng, Jurnal Hukum Khaira Ummah, Vol. 12. No. 3, Semarang, 2017, p. 601-602.

[2] Alvi, Syahri, 2020. Law Enforcement against Policies Who Breached the Code of Conduct, Jurnal Daulat Hukum, Vol. 3. Issue. 3, p. 313-320. 


\section{Internet}

[1] Akuntono, Presiden Jokowi: Indonesia Gawat Darurat Narkoba. http://nasional.kompas.com/read/2015/02/04/10331931/Presiden.Jokowi.I ndonesia.Gawat.Darurat.Narkoba, 2015. 